\title{
Tradisi masyarakat pasca gempa 2006 di sriharjo
}

\author{
Maryani maryani*, Riana nurhayati \\ Kebijakan Pendidikan, Universitas Negeri Yogyakarta \\ *Corresponding Author. e-mail: maryani@uny.ac.id
}

\begin{abstract}
Abstrak
Penelitian ini bertujuan untuk untuk memperoleh pemahaman tentang terjadinya pergeseran tradisi masyarakat pasca gempa 2006 di Sriharjo. Penelitian ini menggunakan pendekatan kualitatif deskriptif dengan jenis studi kasus. penelitian ini dilaksanakan di desa Sriharjo, dusun Mojohuro yang terdiri dari 6 RT dengan jumlah penduduk 857 jiwa dan 264 kepala keluarga dengan menggunakan purposive sampling maka terpilih 1 informan kunci dan 3 informan pendukung. Penelitian ini mengunakan 2 jenis sumber data yakni data primer dan data sekunder, Data primer merupakan data yang diperoleh dengan cara observasi dan wawancara. Data sekunder merupakan data yang diperoleh dengan cara mengkaji dokumen. Teknik analisis data menggunakan teori interaktif miles Huberman. Keabsahan data menggunakan triangulasi sumber dan teknik. Hasil penelitian menunjukkan bahwa tradisi yang berkembang dalam masyarakat Mojohuro, Sriharjo dapat di kelompokkan menjadi 3 hal yakni: 1) Tradisi yang terkait langsung dengan alam. 2) Tradisi yang terkait dengan tahap perkembangan kehidupan manusia. 3) Tradisi yang berasal dari lokal.
\end{abstract}

Kata kunci: tradisi masyarakat, pasca gempa

\begin{abstract}
This study aims to gain an understanding of the shift in community traditions after the 2006 earthquake in Sriharjo. This research uses a descriptive qualitative approach with a type of case study. This research was conducted in Sriharjo Village, Mojohuro Hamlet, which consisted of 6 RTs with a population of 857 people and 264 families using purposive sampling, so 1 key informant and 3 supporting informants were selected. This study uses 2 types of data sources, namely primary data and secondary data. Primary data is data obtained by observation and interviews. Secondary data is data obtained by reviewing documents. The data analysis technique uses interactive Huberman miles theory. The validity of the data used source and technique triangulation. The results showed that the traditions that developed in the Mojohuro, Sriharjo community can be grouped into 3 things, namely:1) Traditions that are directly related to nature. 2) Traditions related to the developmental stages of human life. 3) Traditions that come from local.
\end{abstract}

Keywords: community traditions, post earthquack

This is an open-access article under the CC-BY-SA license.

\section{PENDAHULUAN}

Nagara mawa tata, desa mawa cara merupakan salah satu istilah yang berkembang dalam masyarakat Jawa. Sesanti tersebut berguna untuk menggambarkan perbedaan yang ada dalam setiap kelompok masyarakat. Istilah yang setidaknya mengandung arti bahwa setiap masyarakat mempunyai aturan dan cara masing- masing dalam mengekspesikan dirinya. Begitu pula dengan yang berkembang di masyarakat Sriharjo. 
Kebiasaan atau cara hidup masyarakat suatu daerah sering disebut sebagai tradisi. Tradisi yang berkembang dalam suatu masyarakat diwariskan secara turun temurun oleh pendahulunya. Dalam proses pewarisan tradisi terkadang ada nilai- nilai yang tidak secara tuntas disampaikan kepada generasi selanjutnya. Ketidak tuntasan itu memicu timbulnya perbedaan pandangan antara manusia dalam suatu masyarakat. Soerjano S (1982) dalam Faida dkk (2017: 200-201) mengatakan bahwa serangkaian tradisi atau peradaban atau kebiasaan yang ada dibentuk oleh kebudayaan masyarakat yang dilakukan untuk memenuhi kebutuhan dan kesejahteraan hidup bagi orang-orang yang terlibat di dalam lingkungannya.

Pada 27 Mei 2006, pukul 05.55 WIB masyarakat Yogyakarta dan sekitarnya dikagetkan dengan fenomena alam yakni gempa bumi. Gempa bumi berkekuatan 5,9 Skala Richter telah memporak- porandakan daerah Yogyakarta dan sekitarnya. Gempa bumi terjadi karena ada pergeseran lempeng Eurasia yang berada dibawah permukaan bumi. Lempeng tersebut diperkirakan berada di sepanjang sesar opak yang berada dibawah Sungai Opak. Sungai Opak adalah salah satu sungai yang membelah Yogyakarta dari Gunung Merapi hingga Samudra Indonesia. Titik terjadi gempa berada di pertemuan antara Sungai Oyo dan Sungai Opak. Titik pertemuan itu diperkirakan di sebelah Barat Dusun Gondosuli, Sriharjo, Imogiri, Bantul. Gempa Yogyakarta 8 juni 2011 dalam Rakhman AN. 2012: 186 menginformasikan bahwa bencana gempa bumi yang terjadi di Yogyakarta dan sekitarnya pada Sabtu Wage 27 Mei 2006 berkekuatan 5,9 pada skala Richter, merupakan tipe gempa merusak dengan skala kerusakan 7 MMI (Modified Mercally Intensity). Kekuatan letupan energi setara 40 kiloton TNT alias dua kali lipat ledakan bom Hiroshima.

Gempa bumi yang terjadi di Yogyakarta dan sekitarnya mengakibatkan masyarakat mengalami kerugian material. Kerugian material tersebut dapat dilihat dari banyaknya rumah dan sarana umum yang roboh. Banyak pula diantara mereka yang kehilangan keluarganya. Di samping kerugian berupa material dan korban jiwa, di sisi lain dengan adanya gempa menumbuhkan solidaritas antara masyarakat setempat. Rasa senasib sepenanggungan menjadikan masyarakat Sriharjo lebih guyub.

Secara umum, Sriharjo terdiri dari 13 dusun. Salah satunya adalah dusun Sriharjo. Sriharjo termasuk salah satu dusun yang strategis karena letaknya berada di lingkungan kantor pemerintahan Desa Sriharjo. Walau letaknya cukup strategis, namun masyarakat masih mempertahankan berbagai macam adat- istiadat yang telah ada dalam masyarakat. Atas dasar keunikan tersebut, peneliti tertarik untuk mempelajari lebih jauh lagi mengenai dusun Sriharjo.

Manusia dan kebudayaan merupakan satu kesatuan yang saling berhubungan. Manusia membutuhkan kebudayaan sebagai tempat untuk mengekspresikan diri dan kebudayaan berkembang karena ada manusia sebagai pelaku. Perkembangan kebudayaan beriringan dengan kemajuan teknologi. Kemajuan teknologi biasanya diikuti dengan meningkatnya taraf kehidupan manusia. Sekarang mulai jarang dijumpai upacara adat tradisional masyarakat lokal. Padahal tradisi merupakan bagian dari kehidupan masyarakat yang seharusnya tetap dipertahankan. Walaupun ada upaya- upaya pelestarian namun, itu lebih mengarah pada keuntungan ekonomi semata.

Penelitian ini berangkat dari kegelisahan peneliti dalam melihat perubahan yang ada dalam masyarakat. Adapun suatu hal yang mendasari penelitian ini adalah Bagaimana Tradisi masyarakat pasca gempa 2006 di Sriharjo?

\section{METODE PENELITIAN}

Penelitian ini merupakan penelitian kualitatif deskriptif dengan jenis studi kasus. Studi kasus adalah kegiatan penelitian mengenai keunikan fenomena sosial. Asumsinya bahwa kasus tumbuh dan berkembang dalam masyarakat tidak datang mendadak. Kasus mempunyai akar yang dapat diidentifikasi. (Usman, 2005:21) Peneliti melihat adanya pergeseran tradisi yang berkembang dalam masyarakat pasca gempa 2006 di Sriharjo

Secara umum, penelitian ini dilaksanakan di desa Sriharjo yang terletak di sebelah Selatan kota Yogyakarta. Desa Sriharjo terdiri dari 13 dusun. Salah satu dusun yang ada di desa Mojohuro yang menjadi lokus dalam penelitian ini adalah dusun Mojohuro. Mojohuro terdiri dari 6 RT dengan jumlah penduduk 857 jiwa dan 264 kepala keluarga. 
Informan yang dipilih dalam penelitian ini merupakan orang yang benar- benar mengetahui permasalahan yang sedang diteliti. Melalui informasi dari informan tersebut, kemudian peneliti mengetahui informan selanjutnya, yang akan ditemui. Keuntungan mengunakan teknik ini, peneliti dapat mendapatkan informasi yang banyak dan menarik.

Teknik seperti ini memerlukan waktu yang tidak sebentar, sehingga ketika peneliti menerapkan teknik ini di lapangan peneliti mengalami sedikit hambatan. Adapun hambatan yang dirasakan peneliti selama penelitian ini yakni sering kali informan yang telah dipilih susah untuk ditemui. Guna mengatasi permasalahan tersebut, kemudian peneliti menentukan informan secara acak. Informan bagi peneliti adalah orang yang bisa memberikan informasi sesuai dengan yang diperlukan peneliti. Selama penelitian ini, peneliti telah memperoleh informasi dari 4 orang. Dari 4 orang tersebut dapat dikelompokkan menjadi 1 informan kunci dan 3 informan pendukung.

Penelitian ini mengunakan 2 jenis sumber data yakni data primer dan data sekunder. (Creswell, 2010: 267). Data primer merupakan data yang diperoleh dengan cara observasi dan wawancara. Data sekunder merupakan data yang diperoleh dengan cara mengkaji dokumen.

Pengumpulan data primer dalam penelitian ini dilakukan dengan cara sebagai berikut: 1) observasi yakni peneliti turun langsung ke lapangan untuk mengamati perilaku dan aktivitas masyarakat di Mojohuro. Selama pengamatan peneliti tidak hanya melihat, tetapi juga mendengarkan dan mencatat berbagai aktivitas masyarakat. 2) wawancara, pada proses pengumpulan data peneliti tidak hanya mengamati, peneliti juga melakukan wawancara langsung. Melalui wawancara langsung, peneliti akhirnya mendapatkan lebih banyak informasi terkait dengan permasalahan yang sedang diteliti.

\section{HASIL DAN PEMBAHASAN}

Indonesia merupakan Negara agraris. Pertanian menjadi sektor utama dalam menyokong kesejahteraan masyarakat. Keadaan tersebut juga berlaku di Sriharjo. Mayoritas penduduk Sriharjo bekerja di sektor pertanian. Baik sebagai pemilik lahan maupun sebagai buruh tani. Pertanian yang berkembang di Sriharjo adalah pertanian padi. Masyarakat memilih padi sebagai komoditi utama karena irigasinya cukup memadai. Irigasi tersebut bersumber dari aliran sungai opak yang berada di sebelah barat Sriharjo.

Guna memperlancar aliran air sungai opak pemerintah telah membangun sebuah bendungan atau sering disebut dam oleh masyarakat. Setelah pembuatan dam tersebut kini masyarakat dapat dengan leluasa untuk menanam padi. Masyarakat bisa menanam padi 3 kali selama setahun. Masyarakat menyebutnya sebagai padi, padi, pantun bapak Sulistyo selaku dukuh. Guna menjaga kualitas tanah, ada pula sebagian masyarakat yang menyelingi dengan tanaman palawija. Dapat dilihat pula untuk mengoptimalkan hasil pertanian, masyarakat melakukan sistem tumpang sari. Tumpang sari adalah bentuk penanaman dengan multi tanaman di sebuah lahan. Jadi, selain mereka menanam padi, ada juga yang memagari tanaman dengan tanaman kacang panjang dan sebagainya.

Sebagai masyarakat agraris tentunya, mereka tidak akan terlepas dari upacara adat. Salah satu bentuk upacara adat yang melekat dalam masyarakat agraris dalam kaitannya dengan alam yakni wiwitan. Wiwitan adalah bentuk sedekah pada dewi Sri, dewi kesuburan sebelum melakukan panen. Masyarakat mempersiapkan berbagai macam makanan untuk dipersembahkan pada Dewi Sri. Saat ini hanya sebagian masyarakat saja, yang masih melakukan upacara wiwitan ini. Wahyuni (2017: 89) menyatakan bahwa masyarakat melakukan tradisi wiwitan ini sesuai dengan apa yang diajarkan dan dilakukan oleh para pendahulunya termasuk dari orang tua ataupun tetangga. Tindakan yang dilakukan masyarakat tersebut sesuai dengan tipe traditional rationality (rasionalitas tradisional).

Sejarah adanya wiwitan tersebut menurut masyarakat Mojohuro merupakan upaya untuk mengantisipasi agar panen mereka tidak diganggu oleh orang- orang dari dunia lain. Seperti yang diungkapkan oleh salah satu petani yang ditemui di Mojohuro.

"Sejarahe ya iki, iki panen ajo ngantek dirusuhi, karo lelembut. Nak kowe takon lelembut ki opo mbah? ya menungsa ning ra ketok."

(Sejarahnya itu, agar penen tidak sampai di goda, sama lelembut. Kalau kamu Tanya lelembut itu apa $m b a h$ ? Ya manusia yang tidak kelihatan.) 
Sebelum membawa padi ke lumbung petani biasanya mengatakan kepada yang mengunggu padi, contohnya sebagai berikut:

"Kyai tani karo juru mantani, aku titip ini kasepuh kagowo nang lumbung. Mbok menawa ana kekurangane leh ku ngirim, tukuo dewe nang pasar."

(Kyai Tani dan Juru Mantani, aku titip untuk di bawa ke lumbung. Jika ada kekurangannya dalam mengirim, belilah sendiri di pasar.)

Adapun ubo rampe dalam upacara wiwitan antara lain:

"Sego wadahe wakul. Engko nak ono jajanan pasar wadahe tenong. Tenong kie namnaman pring. Isine yo, sego gurih, terus engko ingkung. Pithik. Gek terus tukon pasar komplit, sak jerone pasar dituku kabeh rakethung mung sethitik- sethitik."

(Nasi tempatnya wakul. Nanti kalo ada jajanan pasar tempatnya tenong. Tenong itu anyaman bambu. Isinya ya, nasi gurih, terus nanti ingkung. Ayam. Terus tukon pasar komplit, seisi pasar dibeli semua mesti hanya sedikit- sedikit.)

Alasan mereka untuk tetap melestarikan tradisi tersebut karena, menurut mereka,

"Nak sing wis mbebaske we bedane apa? Karepe sing mbebaske ki yo ra ana. Ning, nak karepe sing iseh ndawake ki. Masa wong ngragati ki ra ana bedane. Nak ming 2 kresek yo kacek. Wong ora dirusuhi."

(kalo yang sudah membebaskan, bedanya apa? inginnya yang membebaskan ya tidak ada. tapi, keinginan yang masih memperpanjang. Masak orang membiayai tidak ada bedanya. Kalo Cuma 2 karung yang ada lebihnya. Karena tidak diganggu.)

Upacara lain yang berkembang dalam masyarakat Mojohuro, selain kaitan dengan alam adalah upacara yang bersangkutan dengan kehidupan manusia. Tahap kehidupan manusia, antara lain kelahiran, pernikahan, dan kematian. Guna menandai pergantian tahapan tersebut biasanya masyarakat melakukan upacara. Kelahiran adalah awal dari kehidupan manusia. Upacara kelahiran ini oleh masyarakat di tandai dengan brokohan, yakni syukuran sebagai lahirnya manusia ke dunia. Pernikahan yakni tahap yang semestinya dilalui manusia dalam upaya melanggengkan kelangsungan hidup manusia. Melalui pernikahan ini manusia akan meregenerasi manusia. Kematian adalah tahap akhir dari kehidupan manusia.

Pada saat ini, upacara yang berkaitan dengan perkembangan manusia tersebut telah mengalami berbagai pergeseran. Dulu masyarakat mengenal brokohan, puputan, cukur pertama, tedhak siten (turun tanah petama). Hingga saat ini rangkaian upacara tersebut masih ada, walaupun tidak seperti dulu lagi.

Seperti yang disampaikan oleh informan Bapak Sulistyo "Disini yang ada untuk tradisi yang jelas Saparan itu, terus kemudian untuk slametan- slametan orang meninggal misalnya, terus pengantin, kelahiran, selapanan iseh, mitoni iseh. Mitone yo wis podo (ya sama) Cuma bancaan. Lalu dun lemah (turun tanah) itu Cuma bancaan aja. Dadi ora kaya nak mbiyen di lebokke kurungan, di nei mainan, endi enggo sing dicekel sikik dewe, sesuk berarti cah ki arep dadi kuwi. (Jadi tidak seperti dulu, di masukin kurungan, di beri mainan, mana nanti yang di pegang duluan, besok berarti anak tersebut mau jadi itu). Nak ndemok bal dadi (kalo menyentuh bola jadi) pemain bola. Ndemok (menyentuh) raket pemain bulu tangkis."

Upacara adat yang berkembang dalam masyarakat Mojohuro, selain upacara yang terkait dengan pertanian dan upacara perkembangan hidup manusia yakni upacara Saparan dan Merti dusun. Saparan dan Merti dusun merupakan upacara yang berbeda. kalau Merti dusun dilaksanakan 4 tahun sekali dengan menggelar wayang bertempat di balai dusun Mojohura atau di balai dusun Jati. Merti dusun sebagai bentuk membersihkan dusun. Lain halnya dengan Saparan yang dilakukan setiap tahun sekali. Wawancara dengan Bapak Sulistyo, Dukuh Mojohuro pada 4 Mei 2013

“... Kalau tradisi, kalau Sriharjo itu kan ada kelompok Mojohura, Sriharjo kidul, terus Senden, Kampung Senden... terus ada Mijen, Ngentak, terus yang Gayam itu namanya Mbambangan. Sing (yang) ikut Saparan itu, sing ra melu (yang tidak ikut) Sriharjo, sing (yang) Senden sama Mblambangan. Nek (kalau) Mbambangan kuwi gabunge karo (itu gabungnya sama) Kujon nak (kalau) tradisi... nek tradisine ming (kalau tradisi hanya) Saparan tahunan 2 kampung itu ra melu (tidak ikut). Ning nek (tapi kalau) Merti dusun itu sak pedukuhan kabeh melu (satu perdukuhan semuanya ikut). Tapi tradisi gendurenne iku nak Saparan ming nang (kendurinnya itu kalau Saparan hanya di) Gayam, nak (kalau) 
Merti dusun 2 kali. Bar (habis) jum'atan itu nang (di) Gayam itu sing (yang) khusus sing melu (yang ikut) Saparan. Nak (kalau) Merti dusunne engko sing (dusunnya nanti yang) Mbambangan karo (dan) Senden kie melu (itu ikut) gabung kabeh melu (semua ikut).... Merti dusun itu bersih- bersih dusun."

Dusun Mojohuro terdiri dari 6 RT namun, setiap RT mempunyai sebutan kampung sendirisendiri. Ada kampung Senden, Mojohuro kidul, Mblambangan, Ngentak, Mijen, Gunungan dan sebagainya.

Saparan yang berlangsung di Sriharjo berupa kenduri makanan di sendang yang terletak di sungai sebelah Timur dusun Jati. Adapun upacara ini dilakukan guna menjauhkan masyarakat dari bahaya. Hingga saat ini upacara ini masih berlangsung, hanya saja tidak diikuti oleh seluruh masyarakat. Ada masyarakat yang mengatakan yaitu ibu pedagang bahwa,

"Isih, lha piye mbak, nak ning ndesa ki nak ora melu, yo engko do digreneng. Nak melu kuwi ra reti tuntunane."

(Masih, lha gimana mbak, kalau di desa itu kalau tidak ikut, nanti pada digosipin. Kalau

ikut itu tidak tau tuntunannya.)

Berdasarkan informasi dari masyarakat, dapat dikatakan bahwa sebagian dari masyarakat sesungguhnya tidak mengetahui asal mula adanya tradisi. Mereka hanya ikut melestarikan saja. Upacara saparan saat ini telah mengalami komodifikasi. Jika dulu hanya dilaksanakan dengan kenduri di sendang, kini telah berkembang dengan rangkaian acara ngarak gunungan. Gunungan tersebut di bawa dari pendapa balai dusun Sriharjo sampai ke sendang yang ada di dusun Jati. Ngarak gunungan ini, nantinya akan dimasukkan dalam agenda wisata Kabupaten Bantul. Perbedaan masyarakat dalam mengartikan upacara adat biasanya dapat dilihat dari usia mereka. Masyarakat yang hingga saat ini masih melaksanakan upacara sesuai aturan adalah mereka yang tergolong usia lanjut sekitar 70 tahun ke atas. Mereka yang hanya ikut- ikutan adalah mereka yang tergolong usia antara 40 sampai 70 tahun.

Pelaksanaan upacara adat tersebut tidak dapat di pisahkan dari kenduri. Kenduri merupakan salah satu upaya masyarakat dalam merealisasikan do'a mereka dalam bentuk makanan. Salah satu ubo rampe yang ada dalam kenduri misalnya apem, ketan, kolak. Apem, ketan, kolak mempunyai fungsi untuk mengenang leluhur. Apem terbuat dari tepung beras berbentuk bulat pipih. Ketan dan apem sebagai simbol bahwa hubungan antara manusia yang masih hidup dan yang telah meninggal tidak terputus. Apem yang diletakkan di atas ketan mengandung makna bahwa orang yang telah meninggal diharapkan dapat menjaga atau memayungi mereka yang masih hidup. Kolak terbuat dari ketela, pisang, santan, gula dan daun pandan. Kolak rasanya manis dan terbuat dari berbagai macam bahan tersebut mengandung arti bahwa kebersamaan mereka tidak akan pernah luntur. (Herawati, 2007: 150) .

Masyarakat Sriharjo menggolongkan kenduri tersebut dalam 2 macam yakni hajatan dan kenduri rutinan. Kenduri hajatan adalah kenduri yang ada ketika ada hajatan seperti kelahiran, pernikahan, kematian. Kenduri rutin adalah kenduri yang di laksanakan pada hari- hari tertentu. Misalnya Ruwah, Saparan, Merti dusun dan sebagainya.

Pak dukuh mengatakan bahwa saat ini, bentuk kenduri hajatan yang berlangsung di dusun Mojohuro rupanya telah mengalami pergeseran. Dulu orang hadir kenduri pulangnya akan membawa makanan. Kalau sekarang biasanya makanan itu telah diantarkan sebelumnya. Jadi mereka hadir hanya untuk berdo'a saja.

"Wilujengannipun tiyang tilar, menika nggih mlumpuk wedangan ndisik, lajeng tahlilan ngoten niku. Bancaan langsung genduren. ... sak menika genduren riyen, tahlilannipun dalu. Genduren tahlilan nggih wonten, naming racak- racakipun... kersane ingkang gadhah griya menika kantun menika. Dados sak kula menika kantun dereg ingkang dados kersanipun ingkang kagungan griya... hehehe..."

(Selamatan orang meninggal, itu ya berkumpul minum dulu. Kemudian tahlilan seperti itu. Bacaan langsung kenduri. ... sekarang kenduri dulu, tahlilan malamnya. Kenduri tahlilan ya ada, tapi umumnya. ... keinginan yang punya rumah seperti itu ya seperti itu. Seperti saya ini hanya ikut yang menjadi keinginan yang punya rumah. Hehehe....)

Kenduri cara lama memang masih ada tetap berlangsung, tergantung dari orang yang melakukan hajat. Bapak Sulistyo, dukuh Mojohur menyampaikan bahwa 
"Kalau tua- tua yang masih. Biasane bar jum'atan. (Biasanya habis jum'atan.) Kalau dulu pokoke diaturi lenggahan, kirim donga (pokoknya disuruh hadir, kirim do'a) begitu lho. Jadi kirim do'a itu nanti, kita tahlilan dulu, selesai tahlilan, do'a, selesai do'a nanti makan, terus nanti selesai dikasih ubo rampe kenduri itu. Iya yang dibawa pulang itu. Kalau sekarang Cuma beberapa orang yang masih, lainnya, nanti jam- jam segini. Seperti teh, sarimi, gula pasir, beras diantar terus mangke dalu katuran lenggahan (nanti malam disuruh hadir) tahlilan. Kalau itu, belum terlalu lama sekitar 3 tahunan. Golek sing praktis. Iki sesuk iso ilang. Paling teko dhi nei amplop. (Cari yang praktis. Ini besok bisa hilang. Mungkin datang dikasih amplop.) hehehe.... Sak iki go kresek, nak mbiyen rak besek isine sego kebak. (Sekarang pakai kresek/plastik, kalau dulu kan besek isinya nasi penuh."

Berdasarkan uraian di atas tidak hanya bentuk kenduri yang mengalami perubahan, tetapi juga perlengkapan yang digunakan untuk kenduri. Jika dulu tempat makanan atau bahan makanan mengunakan besek (anyaman bambu yang dibentuk kotak biasanya digunakan untuk tempat nasi dan sebagainya), sekarang banyak yang menggunakan tas plastik. Jenis makanannya dalam kenduri untuk kelahiran dan pernikahan nasi, sedangkan untuk kematian biasanya berupa bahan- bahan mentah.

Koentjaraningrat menyampaikan bahwa masyarakat sebagai suatu kesatuan hidup manusia yang berinteraksi sesuai dengan sistem adat- istiadat tertentu yang bersifat berkelanjutan dan terikat oleh suatu rasa identitas bersama. (Koentjaraningrat, 2002: 143- 146). Comte mengartikan masyarakat sebagai keseluruhan organik yang merupakan bagian dari alam seperti halnya gejala fisik. (Comte dalam Johnson, 1986: 82). Berdasarkan uraian tersebut, dapat simpulkan bahwa masyarakat merupakan sekumpulan individu yang berada di suatu tempat dalam waktu yang lama dan terjalin interaksi untuk mencapai tujuan yang sama.

Kebudayaan merupakan hasil interaksi antara manusia dengan manusia, manusia dengan masyarakat, dan manusia dengan lingkungannya. Kebudayaan berubah seiring dengan perkembangan masyarakat. Macionis mendefinisikan kebudayaan sebagai suatu nilai, keyakinan, perilaku dan materi (material objects) yang mengatur kehidupan masyarakat. Kebudayaan terdiri dari simbol, bahasa, nilai dan keyakinan (Macionis dalam Usman, 2004: 105).

Berbicara tentang kebudayaan tidak dapat dilepaskan dari apa yang diungkapkan oleh C. Kluckhon. C. Kluckhohn dalam universal categoris of culture menyebutkan bahwa terdapat 7 unsur kebudayaan. Tujuh unsur kebudayaan tersebut antara lain: peralatan dan perlengkapan hidup manusia, sistem ekonomi, sistem kemasyarakatan, sistem bahasa, sistem kesenian, sistem pengetahuan dan sistem kepercayaan. (Soekanto, 2006: 154). Masing- masing unsur tersebut saling berkaitan satu dengan yang lain. Jika terjadi perubahan dalam salah satu unsur tersebut tentunya akan menimbulkan reaksi terhadap perubahan sistem yang lainnya. Dari 7 unsur tersebut, unsur yang paling rentan mengalami perubahan adalah peralatan dan perlengkapan hidup manusia. Adapun sistem kepercayaan merupakan salah satu unsur yang lambat dalam menerima perubahan dari luar. Sistem kepercayaan identik dengan ritual atau upacara adat.

Upacara adat merupakan salah satu bentuk eksistensi manusia dalam kehidupan. Bentuk upacara adat yang ada di Mojohuro setidaknya ada 3 hal, antara lain:

1. Upacara yang terkait dengan alam.

Salah satu upacara yang berkembang dalam masyarakat agraris adalah upacara yang berkaitan dengan pertanian. Upacara yang terkait dengan pertanian yakni wiwitan, wiwitan adalah sedekah yang dilakukan sebelum panen padi. Upacara wiwitan sudah mulai jarang ditemui di sawah sekitar Mojohuro. Umumnya mereka yang masih melaksanakan upacara wiwitan adalah mereka yang usianya 70 tahun ke atas. Ubo rampe yang digunakan untuk upacara wiwitan antara lain: nasi gurih, ingkung, dan jajanan pasar.

2. Upacara yang terkait dengan kehidupan manusia.

Dalam masyarakat Jawa dikenal tahap kehidupan manusia antara lain: kelahiran, pernikahan dan kematian. Guna menandai setiap peralihan dari satu masa ke masa selanjutnya dilakukan upacara adat. Salah satu bentuk dari upacara adat, masyarakat sering mengunakan istilah kenduri. Saat ini bentuk kenduri telah mengalami perubahan, kenduri tidak hanya berupa nasi. Kenduri untuk slamatan orang meninggal berupa bahan mentah yang dibagikan pada siang 
hari. Walaupun memang masih ada yang pembagian kendurinya setelah tahlilan namun, itu hanya beberapa saja.

3. Upacara lokal masyarakat Sriharjo

Upacara lokal yang berkembang dalam masyarakat Mojohuro yakni Saparan dan Merti dusun. Saparan dilaksanakan setiap tahun sekali, sedangkan Merti dusun dilakukan setiap 4 tahun sekali. Bentuk Merti dusun yang ada di Mojohuro saat ini telah mengalami perubahan. Jika dulu hanya berupa pertunjukan wayang, kini ditambah dengan acara ngarak gunungan. Ngarak gunungan ini merupakan bentuk adopsi dari tradisi yang berkembang di lingkungan keraton Ngayogjakarta. Acara ngarak gunungan ini sebagai salah satu cara untuk memperlihatkan eksistensi masyarakat Mojohuro dalam kehidupannya.

Tradisi dusun/ deso (Suryaningsi, Tini. 2019: 266) merupakan tradisi orang jawa. Merti deso yang berarti bersih desa termasuk dalam budaya local yang diwarisakn secara turun temurun yang diwariskan dari nenek moyang mereka. Tradisi merti deso masih berlangsung dibeberapa daerah.

Macionis (1987), perubahan sosial merupakan tranformasi dalam organisasi masyarakat, pola pikir dan perilaku pada waktu tertentu. (Macionis dalam Sztompka, 2011: 5) Perubahan sosial sesuai yang dikatakan oleh Macionis tersebut identik dengan adanya proses kemajuan suatu masyarakat. Comte juga pernah membagi hukum kemajuan suatu masyarakat terbagi dalam 3 tahap yakni: tahap teologis, tahap metafisis dan tahap positif. (Laeyendecker, 1991: 146) Pada tahap teologis manusia masih percaya dengan adanya kekuatan benda- benda animisme dan dinamisme.

Perubahan sosial erat kaitannya dengan rasionalitas yang diungkapkan oleh Weber (Johnson, 1986: 219- 222) antara lain:

1. Rasionalitas instrumental adalah suatu tindakan sosial yang mempunyai tujuan dan pilihan alat yang digunakan untuk mencapainya.

2. Rasionalitas berorientasi nilai mengartikan bahwa alat hanyalah obyek yang gunakan sebagai pertimbangan karena tujuan sudah melekat dalam nilai- nilai manusia.

3. Tindakan tradisional adalah suatu tindakan yang tidak menggunakan pertimbangan rasional.

4. Tindakan afektif adalah suatu tindakan yang terjadi karena dorongan emosi.

Melalui tindakan rasional Weber tersebut kita dapat menjelaskan timbulnya perbedaan pandangan dalam masyarakat Mojohuro dalam melihat upacara adat. Perbedaan pandangan tersebut tidak hanya dapat dilihat dari segi umur tapi, juga cara berpikir masyarakat. Masyarakat yang masih menginginkan tradisi tersebut tetap ada tentunya mereka dapat digolongkan sebagai penganut tradisi rasionalitas instrumental. Berbeda halnya dengan mereka yang menganut rasionalitas nilai, mereka cenderung lebih terbuka dengan pemikiran baru. Mereka tidak terlalu bermasalah dengan ada atau tidaknya sesaji ketika melangsungkan upacara.

Perubahan dalam pelaksanaan upacara adat di Mojohuro timbul karena adanya perubahan cara berpikir masyarakat Mojohuro. Masyarakat saat ini lebih memperhitungkan biaya, waktu dan tenaga. Cara berpikir masyarakat saat ini lebih rasional dan logis. Hal ini sesuai dengan hasil penelitian yang dilakukan oleh Saputra, Akmal, 2017: 120) yang menyatakan bahwa Pasca gempa dan tsunami, persoalan yang paling mencolok terjadi perubahan adalah kehilangan nilai-nilai kegotongroyongan dan kebersamaan pada masyarakat, nilai-nilai itu menjadi pudar. Kedatangan orang asing di suatu daerah tentunya akan meninggalkan suatu pengetahuan baru bagi masyarakat yang dikunjungi. Pengetahuan baru tersebut dapat berupa kebiasaan atau cara hidup. Masyarakat akhirnya mengadopsi dan membiasakan diri dengan cara hidup tersebut.

Perubahan upacara adat juga dapat terjadi akibat adanya pembangunan. Pembangunan merupakan salah satu cara untuk meningkatkan kehidupan suatu masyarakat. Pembangunan sering kali mengabaikan tradisi lokal. Pembangunan rumah dalam kondisi darurat berupa gempa bumi, tentunya tidak lagi memperhitungkan adanya penanggalan Jawa.

\section{Kesimpulan}

Setiap masyarakat mengalami perubahan sesuai dengan masanya. Upacara adat yang langsung di Mojohuro kini telah banyak mengalami berbagai perubahan. Secara umum, tradisi yang berkembang dalam masyarakat Mojohuro, Sriharjo dapat di kelompokkan menjadi 3 hal yakni: Tradisi yang terkait langsung dengan alam. Tradisi yang terkait dengan tahap perkembangan 
kehidupan manusia. Tradisi yang berasal dari lokal. Perubahan kenduri yang berlangsung selama ini, menunjukkan bahwa semakin meningkatnya taraf kehidupan masyarakat. lebih lanjut lagi, berkurangnya tradisi yang berkembang dalam masyarakat Mojohuro karena saat ini masyarakat dapat dikatakan telah mengalami perubahan rasionalitas.

\section{DAFTAR PUSTAKA}

Creswell. John W. 2010. Research Design (Pendekatan kualitatif, Kuantitatif dan Mixed) Edisi Ketiga. Dialih bahasakan oleh Achmad Fawaid. Dari judul asli Research Design (Qualitative, Quantitative, and Mixed Methods Approaches). Penerbit Pustaka Pelajar. Yogyakarta.

Faida. Lies RW. Dkk. 2017. Tradisi Masyarakat Selo dan Pariwisata di Taman Nasional Gunung Merbabu, Boyolali Jawa Tengah" SASDAYA Gadjah Mada Journal of Humanities. https://jurnal.ugm.ac.id/sasdayajournal/article/view/27782/16993

Herawati. Isni. 2007. Makna Simbolik Sajen Slametan Tingkepan dalam Jatra Volume II No. 3 Juni 2007. Penerbit BPSNT. Yogyakarta.

Johnson. Doyle Paul. 1986. Teori Sosiologi Klasik dan Modern. (diterjemahkan oleh Robert MZ Lawang). Penerbit PT. Gramedia. Jakarta.

Koentjaraningrat. 2002. Pengantar Ilmu Antropologi. Penerbit PT. Rineka Cipta. Jakarta Laeyendecker. L. 1991. Tata, Perubahan dan Ketimpangan. (Suatu pengantar sejarah sosiologi) Cetakan Ketiga. Dialih bahasakan oleh Samekto. Dari judul asli Orde, Verandering, Ongelijkheid (Ean inleiding in de geshiedenis van de sociologie). Penerbit PT. Gramedia Pustaka Utama. Jakarta.

Rakhman. Arie Noor dan Kuswardani. Istiana. 2012. Studi Kasus Gemp BumiYogyakarta 2006: Pemberdayaan Kearifan Lokal Sebagai Modal Masyarakat Tangguh Menghadapi Bencana. Prosiding Seminar Nasional Aplikasi Sains \#\& Teknologi (SNAST) Periode III. Yogyakarta, 3 November 2012. http://repository.akprind.ac.id/sites/files/conferenceproceedings/2012/rakhman_15419.pdf

Saputra. Akmal. 2017. Perubahan Sosial Masyarakat Aceh Jaya Pasca Gempa dan Tsunami 2004. Community: Pengawas Dinamika Sosial. Volume 3, Nomor 1, April 2017. http://jurnal.utu.ac.id/jcommunity/article/view/149/139

Soekanto. Soerjono. 2006. Sosiologi Suatu Pengantar. Ed Baru 40. Penerbit Raja Grafindo Persada. Jakarta

Suryaningsi. Tini. 2019. Tradisi Merti Deso Di Margolembo. Pangadereng: Jurnal Hasil Penelitian Ilmu Sosial dan Humaniora. Volume 5 No. 2, Desember 2019: 261-274. https://jurnalpangadereng.kemdikbud.go.id/index.php/pangadereng/article/view/36

Sztompka. Piotr. 2011. Sosiologi Perubahan Sosial. Penerbit Prenada. Jakarta.

Usman. Sunyoto. 2004. Sosiologi, Sejarah, Teori dan Metodologi. Penerbit Cired. Yogyakarta.

Usman. Sunyoto.2005. Pengantar Metode Penelitian Sosial. Penerbit Fisipol UGM. Yogyakarta.

Wahyuni. Anik Tri \& Pinasti, Indah Sri. 2017. Perubahan Tradisi Wiwitan dalam Era Modernisasi (studi Pada Masyarakat Petani di Desa Balak, Kecamatan Cawas, Kabupaten Klaten). Jurnal Pendidikan Sosiologi. https://core.ac.uk/download/pdf/132422009.pdf 